\title{
Tempo
}

http://journals.cambridge.org/TEM

Additional services for Tempo:

Email alerts: Click here

Subscriptions: Click here

Commercial reprints: Click here

Terms of use : Click here

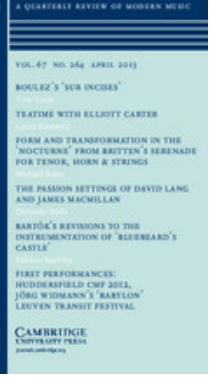

\section{Ligeti's Chamber Concerto - Summation or Turning Point?}

\author{
Michael Searby
}

Tempo / Issue 168 / March 1989, pp 30 - 34

DOI: 10.1017/S004029820002492X, Published online: 04 February 2010

Link to this article: http://journals.cambridge.org/abstract S004029820002492X

How to cite this article:

Michael Searby (1989). Ligeti's Chamber Concerto - Summation or Turning Point?. Tempo, pp 30-34 doi:10.1017/S004029820002492X

Request Permissions : $\underline{\text { Click here }}$ 


\section{Michael Searby}

\section{Ligeti's Chamber Concerto - Summation or Turning Point?}

György Ligeti's music of the 1970s shows a distinct change of direction in its main preoccupation. Up to the middle 1970s his dominant concern was with textural elements, note-cluster development and the use of strict canons to create 'Mikropolyphonie'. Mikropolyphonie is usually generated by a canonic development where each entry uses the same pitch array but also has a unique rhythmic shape and is therefore unlike.a normal canon (Example 1 , below, is a good illustration). Melody, noncluster harmony, and rhythmic clarity were not usually significant features. However the opera Le Grande Macabre (1974-77) shows a clear, unambiguous change of approach and a greater eclecticism; as Ligeti states: 'In Le Grande Macabre there is less of the static, slowly, gradually evolving music. I felt I had worn these types out'. '

This change can be seen to have its roots in the music of the late 1960s, particularly the Chamber Concerto, although the evolution towards his total recapture of melody and harmony in the 1980s was gradual and fluctuating. The Chamber Concerto has an ambivalent nature, because although the first three movements are closely related to the processes in late 1960s works - for example Lontano (1967), Lux Aetema (1966) and the Second String Quartet (1968) - the compositional process itself appears to evolve throughout, reaching a new and more open-ended process in the last movement. The significant features of this new process are the unravelling of the tightlycontrolled canons, which are important in much of the Chamber Concerto and many of Ligeti's other works; and also the rediscovery, however fleeting, of melody.

The Chamber Concerto (1969-70) is for eleven orchestral instruments, ${ }^{2}$ harpsichord doubling Hammond Organ, and piano doubling celeste; it has four movements. The first is an elusive, texture-based movement containing much rapid figuration. The structural outline is simple because, in common with Lux Aeterna and Lontano, it consists of a slowly evolving and expanding pitch cluster. This background cluster structure is articulated in the foreground by canonic development, a common feature in much of Ligeti's work. (See Example 1.) However only the resulting textural Mikropolyphonie can be heard, not the individual

Ex.1 1st Movement bars 1-2

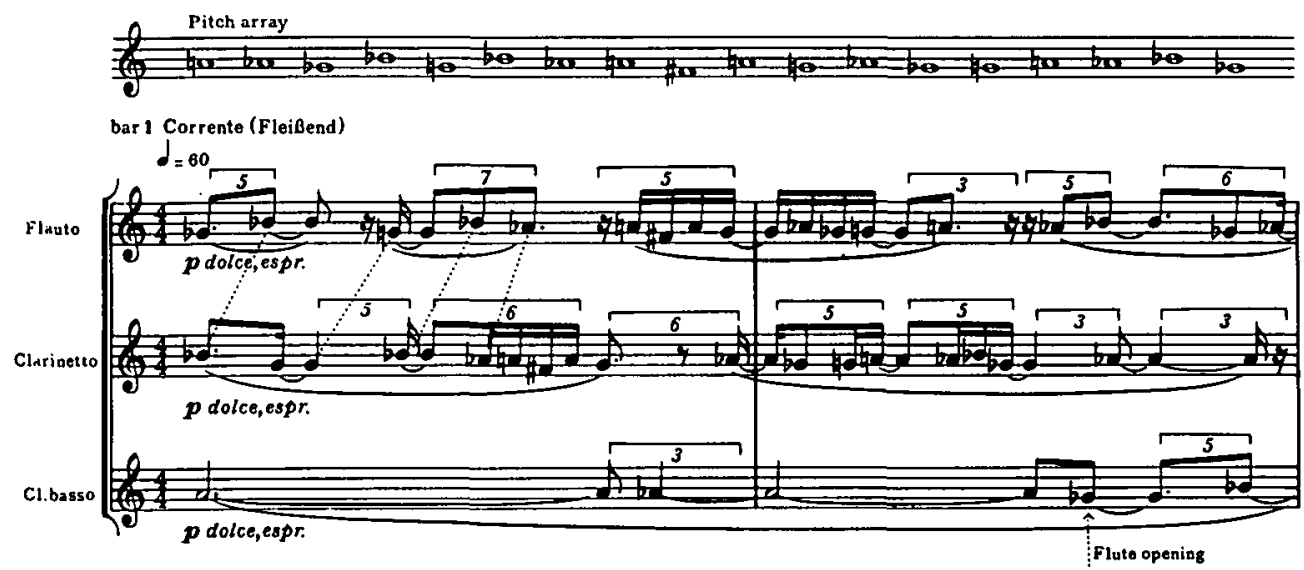

' Gyorgy Ligeti, Ligeti in conversation (Eulenberg: London, 1983), p.67.
${ }^{2}$ Flute doubling piccolo, oboc doubling oboc d'amore and cor anglais, clarinet, bass clarinet doubling second clarinct, horn, trombonc, two violins, viola, violoncello, and double bass. 
canons. In the first movement the complexity of the texture is quite distinctive (especially, for example, bars 47-50 and the final six bars).

By contrast, the third movement of the Chamber Concerto reflects one of Ligeti's recurrent obsessions: that of mechanical objects in general and clocks in particular - also seen in the Poème Symphonique (1962) for 100 metronomes, the third movement of the Second String Quartet, and Continuum for harpsichord (1968). The movement has basically two types of texture. The first consists of indeterminate fast articulation in all the instruments (perhaps a 'grained' version of the cluster development); the second contains ultimately every instrument, iterating regularly at a different tempo. This takes the concept of simultaneous tempi, which can also be seen in the second movement, to an extreme.

The second movement, nevertheless, cannot be as easily identified as one of Ligeti's compositional process types as the movements which encompass it. What is significant is the slowing down of Mikropolyphonie in the first section (bars 1-35), so that the dynamically highlighted melodic lines in the oboe d'amore, horn, and trombone can be heard. This increased melodic element can be seen in later works like Melodien (1971) and the Double Concerto (1972) and also in the earlier Ten Pieces for Wind Quintet (1968). The second section, from bar $39,{ }^{3}$ shows a distinct development of the canonic compositional process. The initial cluster at bar 39 expands gradually, with each note in the cluster initiating a mobile chromatic line (see Example 2) which gradually evolves, tending towards a stable position (at bar 73) consisting of interlocking superimposed fifth chords.
The melodic line of each instrument skips between all the chromatic lines, disguising this underlying movement - the motion that is created is somewhat like 'running on the spot'. This differs from the cluster movement more commonly found in Ligeti's works in three significant ways: the background chromatic lines are aurally more important than the canons (or possibly even the clusters); since the number of chromatic lines remains the same throughout, the germ clusters have a constant number of notes; and the process of pitch-change occurs at a greater velocity than in many other works. The aural effect is one of the frenetic dissipation of potential energy until it gradually reaches an equilibrium.

The process of gradual change of pitch material in many of Ligeti's works up to the composition of the Chamber Concerto is here transformed, so that the chromatic changes of the background cluster (rather than within it), have become the contrapuntal element. Whereas in the first movement the canonic construction provides the complex counterpoint, in the second movement the most aurally apparent counterpoint (particularly at the outer pitch limits) is provided by the background chromatic lines, which govern the content of the foreground melodic lines. This is a substantial change in compositional design, and perhaps suggests that Ligeti was becoming dissatisfied with the canonic constructions which dominate his work of that period.

The use of chromatic lines is quite rare in Ligeti's music and, in addition to the background chromatic counterpoint of the second movement, the lower instrumental parts mirror this in a more overt manner ${ }^{4}$ (see Example 3).

Ex.2 2nd Movement bars 51-2
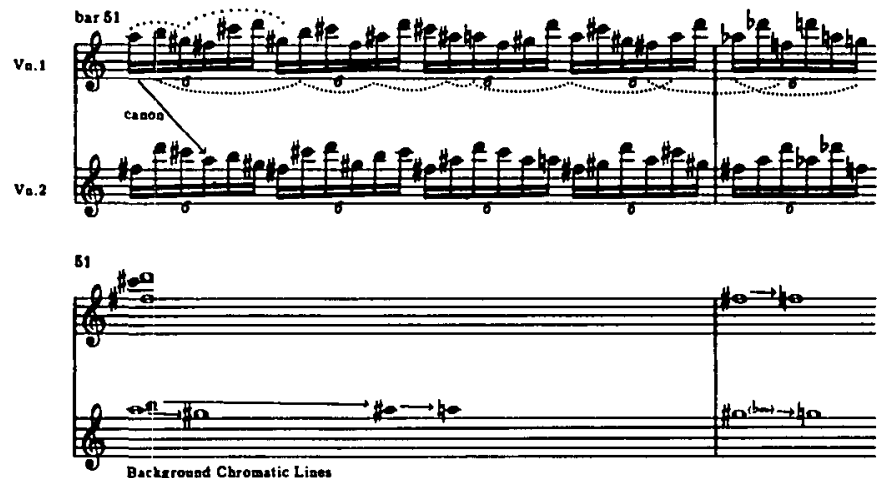

\footnotetext{
${ }^{3}$ Between the two main sections there is a bridging section of stasis (bars 35-9) which is doubled augmented fourth, a typical device in Ligeti's music to halt a process or create a

4 This melodic chromaticism can also be seen in the first movement of the Second String Quartet but with octave displacements.
} structural division. 
Ex.3 2nd Movement bars 40.43

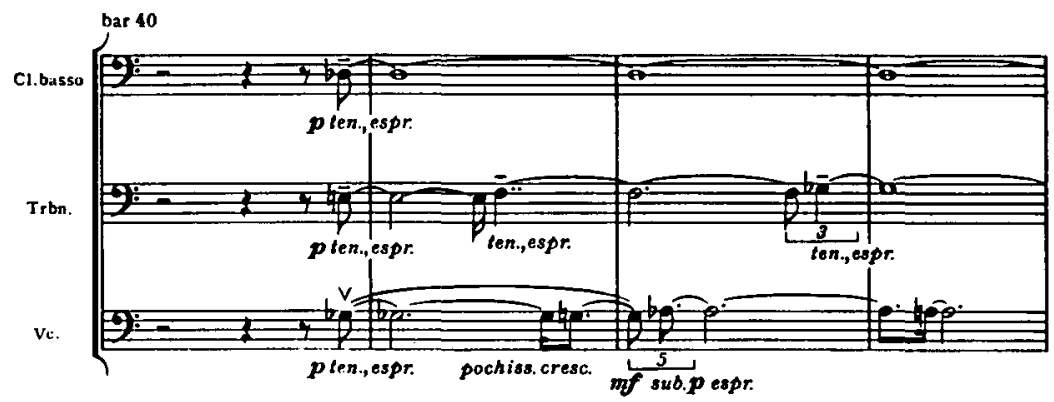

Chromaticism can also be seen elsewhere in the Chamber Concerto, for example in bars 12-40 in the third movement (see Example 4), which can be viewed as a simpler and clearer model of the process present in the second movement.

rhythm, preserves the cluster and prevents any pitch having an unwanted emphasis. However, in the last movement, this solution has metamorphosed into a process which gives the composer more freedom while still preserving

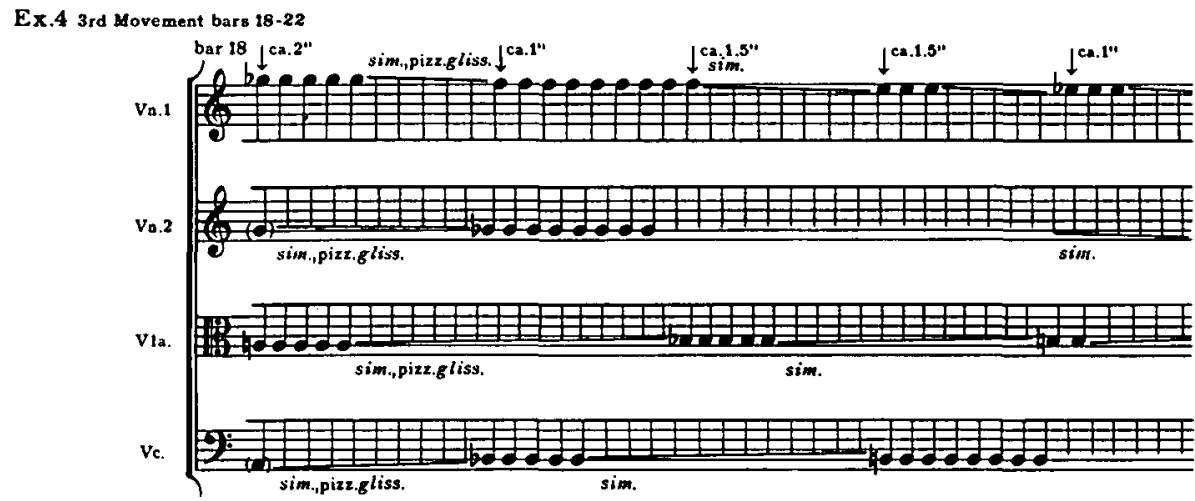

In the former case (Ex.4) the process consists of a pattern of canonic chromatic lines, rising and falling from the initial $A b$ at bar 12. The process of the third movement is a simplification of that of the second, because it does not involve an audible interlocking canonic structure: thereby continuing the gradual transformation of the work's, and perhaps Ligeti's, overriding compositional process.

The gradual erosion of the canonic construction in the Chamber Concerto could perhaps suggest a dénoviement in the last movement. Here, the canonic structure which has been weakened in the second and third movements is only hinted at. The actual texture and background cluster structure changes little - which suggests that canonic construction is not essential to create Mikropolyphonie. Ligeti's canonic construction is perhaps merely one possible solution to the problem of distributing pitches of the controlling background clusters into a polyphonic texture. It operates as a pitch regulator ${ }^{3}$ and, in conjunction with the fluid

\footnotetext{
'See Ligeti discussing Nono's usc of the chromatic scale in a serial structure in 'Mctamorphoses of Musical Form', Die Reihe 7 (1965), p.6.
}

its basic regulatory function, as the background cluster development is preserved.

A counterbalancing feature is that as the pitch material becomes freer, the rhythm and independence of parts becomes very restricted in places; for example bars 18-23 (see Example 5). Perhaps this shows that Ligeti's apparent movement towards freedom from constructional control is only illusory: that complete freedom is as undesirable as complete control. ${ }^{\circ}$ Instead he surrenders one type of control for another, from canonic construction to parellel contour, homophony, and also 12-note rows (bars 24-29). A relevant observation is made by Harrison Birtwistle, as cited by Michael Hall:

Composition is concerned with taking decisions, but if a composer has to take decisions about everything that happens in music he will seize up and rapidly come to halt. ${ }^{7}$

The Chamber Concerto as a whole seems to have as its fundamental structural tenet the gradual evolution of the compositional process

- Ligeti spends much of 'Metamorphoses of Musical Form' repudiating intcgral scrialism.

' Michacl Hall, Hamison Binwistle (Robson: London, 1984), p.10. 


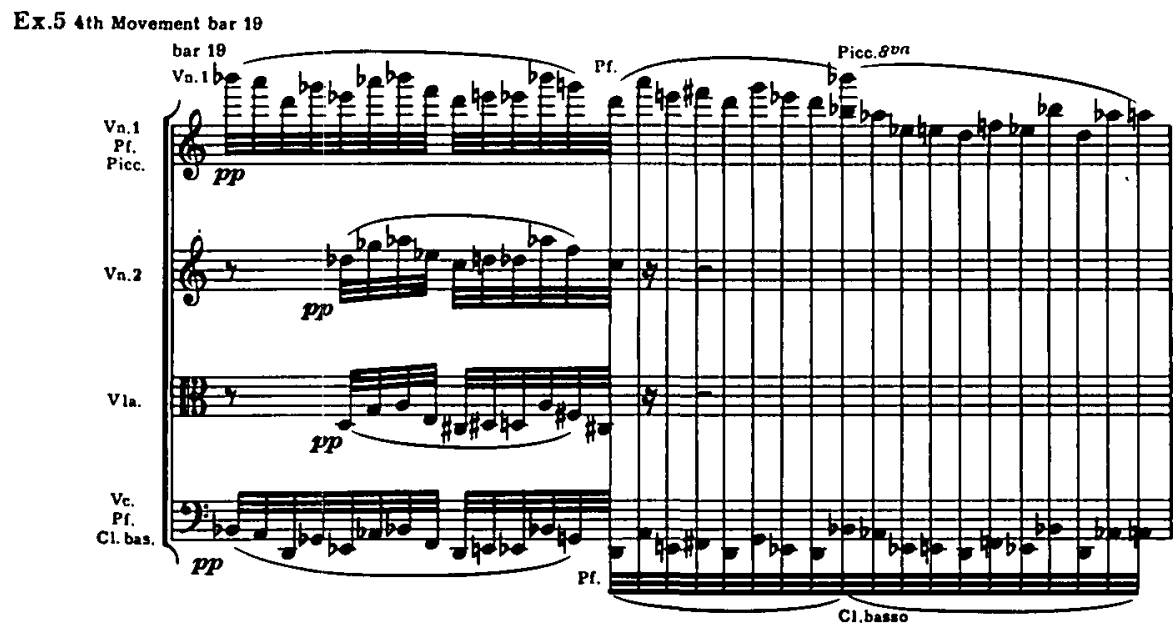

itself. It appears that Ligeti is experimenting with a gradually evolving compositional approach, perhaps more often confined to a composer's sketchpad, and maybe in the spirit of Ligeti's criticism of mobile form:

It seems to me it would me much more worthwhile to try and achieve a compositional design of the process of change. ${ }^{8}$

This can be seen as a reflection of his compositional approach, not only in terms of Mikropolyphonic music, but also perhaps in relation to the concept of a compositional design which itself evolves throughout a work, as we see in the Chamber Concerto.

In the Chamber Concerto, from a structural and compositional process view, one can detect a change of approach which develops over the work as a whole. In addition, there is a rediscovery of melody, which had previously bẹen obscured in Ligeti's complex textural surfaces. This rediscovery can be considered as a significant shift in a broader context of the music of the 1970s. Stockhausen has also shown this change, and enunciates the need for melody (as a distillation of the preceding music) in a manner which is not devalued by overuse. In conversation with Mya Tannenbaum he has said:

The hours that pass from dawn to dusk don't contain more than a moment in which one has a wish to sing. In this sense there is in every one of my compositions the moment in which I sing my song too. And it's the most beautiful, the most concentrated song possible. All the rest is just preparation for that moment. ${ }^{9}$

Ligeti displays a similar attitude in the Chamber Concerto's last movement, where the 12-note

\footnotetext{
8 'Mctamorphoses of Musical Form', p. 19.

- Mya Tannenbaum, Conversations with Stockhausen, trans. D. Butchart (Clarendon Press: Oxford, 1987), p.73.
}

melodies of the horn and piccolo in bars 24-9 create such a 'moment'. These tone-rows are perhaps a reminiscence of the Second Viennese School - perhaps a nostalgic yearning for a time of greater melodic freedom. It is the only clear melodic expression in the work (the melodies in the second movement are still rather veiled) and must be seen as a significant feature in his compositional development. Its result can be heard in most of Ligeti's work from Le Grand Macabre, culminating in the unambiguously melodic Horn Trio (1983). As Paul Griffiths observes:

[The Horn Trio]... has grown out of the earlier works at the end of gradual recovery with the return first of harmony, then of melody, then of harmonic movement. ${ }^{10}$

Melodic activity of a more ambiguous kind can be seen in the solo horn, trombone, and oboe d'amore parts of the Chamber Concerto's second movement. They function in analogous fashion to a magnifying glass, highlighting the complex, weaving pattern in the accompanying instruments, rhythmically augmenting and clarifying their material (see Example 6). This development is taken a step further in Melodien (1971) in which the Mikropolyphonie becomes 'macro' - allowing much greater melodic clarity. Ligeti himself states:

One might say that the micropolyphony of these pieces [Chamber Concerto and the Second String Quartet] has become less 'micro', the musical texture being balanced on the threshold between imperceptible musical factors and others which are perceptible as shapes. ${ }^{11}$

The Chamber Concerto, therefore, can be

\footnotetext{
${ }^{10}$ Paul Griffiths, Gyorgy Ligeti (Robson: London, 1983) p.31.

"Ligeti in Conversation, p.137.
} 


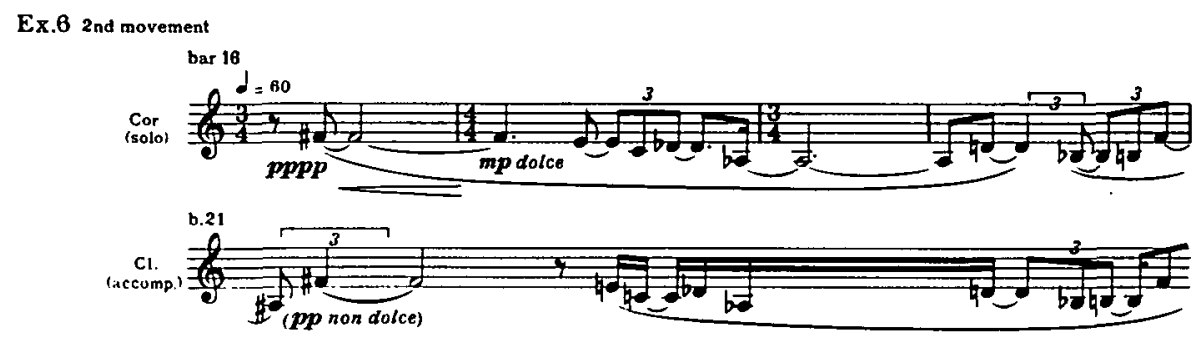

viewed from two standpoints: it is either a culmination of various trends in Ligeti's music, or it shows a considerable departure from his highly developed compositional process. However, neither approach gives a complete and accurate picture of the work. The more straightforward first and third movements can be related directly to earlier and contemporaneous works, but they show a greater sophistication in the use of the Mikropolyphonic compositional process. In that sense, the Chamber Concerto is culminative, as it takes an idea to a pinnacle of complexity and subtlety. The second and fourth movements do not support this conclusion, as they indicate a distinctly different and radical change to the accepted processes that Ligeti had been using up to that point. The second movement is constructed out of background chromatic lines which are spun by the canonic foreground threads, and the last movement moves into a new, more varied, and apparently freer mode. ${ }^{12}$ Thus the work can be seen to contain an evolution of a compositional methodology.

A comparison of the two possible orientations of the work suggests that the Chamber Concerto

\footnotetext{
12 It is very difficult to sec a pattern in the pitch generation of the lase movement - it may have been generated in a similar way to aspects of Birtwistle's music which uses random number tables.
}

has a dual function within Ligeti's oeuvre. It appears Ligeti has reached a limit of sophistication in the first movement that perhaps motivates him to explore new procedures in the other movements. His attitude toward experimentation in music is clearly indicated in a conversation with Josef Hausler:

... creating something that already exists is not interesting for me. If something new has been tried out and a result has emerged from it, it is not worth making the same experiment agains. ${ }^{13}$

What is less clear is how this significant change directly affects his subequent work, as there is little evidence up to the composition of Le Grand Macabre of these new ideas being explored further to any depth. Perhaps a possible explanation is that in the Chamber Concerto Ligeti had experimented to a degree which was some distance from his mature language of the 1960 s, especially in the last movement, and it was some time before the changes in compositional process inherent in this work could be absorbed into a more complete language. The fruits of this greater control can perhaps be seen in the Horn Trio and the Piano Concerto.

${ }^{13}$ Ligeti in Conversation, p. 94.

Musical examples by kind permission of Schott \& Co. Letd. 
Après le succès de la saison parisienne de 1909, Diaghilev pensa à un ballet tiré d'un conte russe, $L ' O i-$ seau de Feu. Le scénario fut mis au point par son entourage et notamment par Fokine. Après avoir songé à en demander la musique à Liadov, il passa commande en décembre 1909 à Stravinsky. Le 18 mai 1910, la partition était achevée et, le 25 juin suivant, l'œuvre était représentée avec un vif succès à l'Opéra de Paris. C'était à la fois la première visite du musicien à Paris et son entrée sur la scène musicale européenne.

Le Conservatoire de $\mathrm{Mu}$ sique de Genève possède, depuis 1920 , le premier manuscrit de la partition du ballet L'Oiseau de Feu (StPétersbourg, 1910). Ce document fut remis à linstitution par le petit-fils du fondateur. Mécène lui-même, Jean Bartholoni avait acheté le manuscrit a Stravinsky en 1918 probablement. Fondé ẹn 1835, le Conservatoire de Musique de Genève fêta en 1985 son $150^{\circ}$ anniversaire, qui coïncida avec le $75^{\mathrm{e}}$ anniversaire de la première représentation de L'Oiseau de Feu.

Pour marquer ce double événement, les responsables du célèbre établissement ont donc décidé d'éditer un facsimilé en couleur du précieux manuscrit suivi d'études et de commentaires de Louis Cyr, Jean-Jacques Eigeldinger et Pierre Wissmer. Cette publication prestigieuse, éditée à 500 exemplaires (dont 150 hors commerce) est réalisée avec l'accord des éditions Schott et le concours d'artisans nourris des traditions helvétiques de bienfacture.

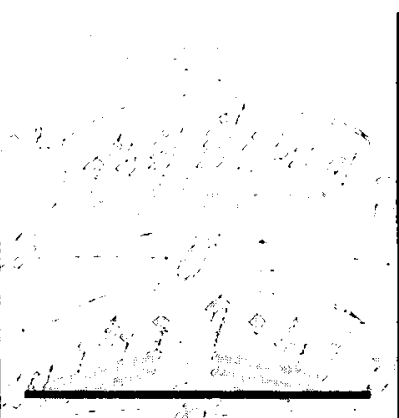

\section{Igor Stravinsky}

\section{L'OISEAU DE FEU}

Conte dansé en deux tableaux, partition d'orchestre, 1909-1910. Fac-similé en coúleurs du manuscrit autographe signé et daté à la fin (en russe): St-Pétersbourg, $19105 / 18$ mai lgor Stravinsky. Conservatoire de Musique de Gérève, en dépót à la Bibliothèque Bodmer, Cologny. Etudes et commen taires de Louis Cyr Jean'jacques Eigeldinger ef Pierre Wissmer (français-anglaiśs. Reproduit par le Consenvatoire de Musiquie de Genève pour son $150^{\mathrm{e}}$ anniversaire. Genève, 1985.

1 volume in-folio $(34 \times 45)$ de 240 pages, relié.

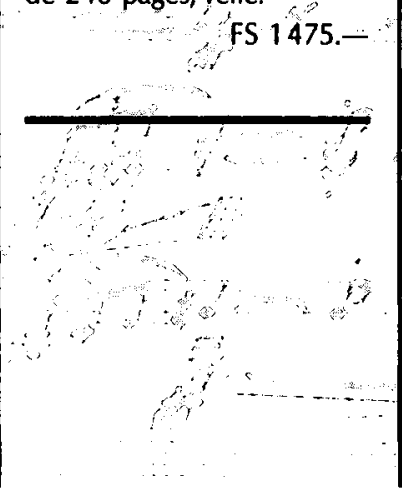

After the success of the Parisian season of 1909 Diaghilev thought of creating $a$ ballet entitled The Firebird after a Russian fairy tale. Its scenario mas worked out by his followers and more particularly Fokine. Having originally thought of Liadov for the music, he finally asked Stravinsky, in December 1909, to write it. On May 18, 1910 the score was completed and on the following June 25, the work was performed at the Paris Opera with great success. It was the musician's first visit to Paris as well as his introduction to the European musical scene.

The Conservatoire de Musique of Geneva has possessed, since 1920, the first manuscript of the Fitebird ballet score (St-Petersburg, 1910). It was the founder's grandson who gave the document to the institution. Jean Bartholoni patron himself - probably bought the manuscript from Sträinsky in 1918. Founded in the year 1835, the Conservatoire de Musique of Geneva celebrated in 1985 its hundred and fiftieth anniversary, which coincided with the sevent $y$-fifth anniversary of the Firebird's first per formance.

In order to mark this outstanding double event, it has been decided by the celebrated Genevese institution to publish a colour facsimile of the precious manuscripit. It comprises studies, and commentaries by Louis $C y$, Jean-Jacques Eigeldinger ẩ Pierre Wissmer. This prestigious realization, benefiting from the tradition of Swiss craftmanship, was produced with permission of Schott Editions and published in 500, of which 150 non commercial copies.

\section{EDITIONS MINKOFF}

8, rue Eynard, 1211 Genève 12, tél. (022) 204660, fax (022) 202857

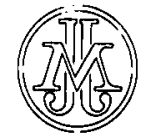

For U.K. : Early Music Shop. 38 Manningham Lane. Bradford, West Yorkshire, BD1 3EA 


\title{
Antal Doráti (1906-88)
}

\author{
Variazioni sopra un Tema di Béla Bartók (1974) \\ for solo piano (Theme from Mikrokosmos I, No.15) \\ Öt Kánon (1970) \\ five canons for a cappella chorus \\ to texts by Deszö Keresztúry \\ Imádság (Prayer) (1984) \\ for a cappella mixed chorus \\ text by Deszö Keresztúry
}

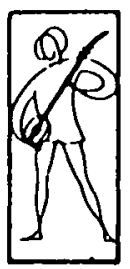

\section{Editio Musica Budapest Sole U.K. Agents: Boosey \& Hawkes Music Publishers Limited}

Boosey \& Hawkes Music Publishers Limited

\section{Antal Doráti}

(1906-88)

Scores for hire

Le Chemin

cantata for voices and orchestra

Chamber Music

for soprano and 25 players

Die Stimmen

song-cycle for bass voice and piano

Divertimento

for oboe and orchestra

Concerto for Cello and Orchestra

In the Beginning

for bass-baritone, oboe, cello and percussion

String Quartet
The Chosen

opera in three acts

Trittico

for oboe, oboe d'amore and cor anglais

with strings or piano

Querela pacis (Symphony No 2)

On Sale

Cinq Pleces Pour le Hautbois

Duo Concertante

for oboe and piano (in preparation)

Further information from the Promotion Department

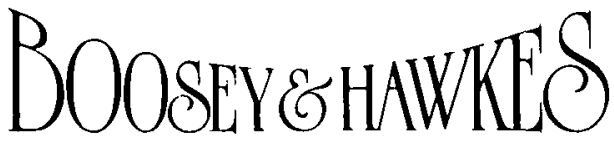

